\title{
Synthesis, growth, and characterisation of a novel organic-inorganic perovskite-type hybrid system based on glycine
}

\author{
A. Kaiba* ${ }^{\text {a* }}$ Mohammed H. Geesi ${ }^{\mathbf{b}}$, P. Guionneau ${ }^{\mathbf{c}}$, Yassine Riadi ${ }^{\mathrm{d}}$, Talal A. Aljohani ${ }^{\mathrm{e}}$, Ammar \\ Elsanousi ${ }^{\mathbf{a}}$, Oussama Ouerghi ${ }^{\mathbf{a}}$.

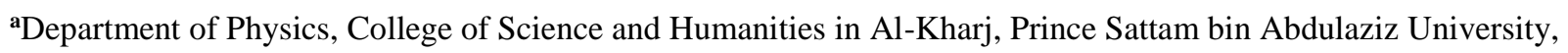 \\ Al-Kharj 11942, Saudi Arabia \\ bepartment of Chemistry, College of Science and Humanities in Al-Kharj, Prince Sattam bin Abdulaziz University, \\ Al-Kharj 11942, Saudi Arabia \\ 'CNRS, Univ. Bordeaux, ICMCB, UPR 9048, 87, Avenue du Docteur Schweitzer, F-33600 Pessac, France \\ ${ }^{d}$ Prince Sattam bin Abdulaziz University, College of Pharmacy, P.O. Box 173, Alkharj 11942, Saudi Arabia \\ ${ }^{\mathrm{e}}$ King Abdulaziz City for Science and Technology, Riyadh, Saudi Arabia
}

\begin{abstract}
A new organic-inorganic hybrid with the empirical formula $\left[\mathrm{NH}_{3}-\mathrm{CH}_{2}-\mathrm{COOH}\right] \mathrm{CdCl}_{3} \cdot \mathrm{H}_{2} \mathrm{O}$ has been crystallised, and the structure was solved at room temperature (system (orthorhombic), space group (Pcam), unit parameters cell ( $\boldsymbol{a}=7.433(10) \AA, \boldsymbol{b}=7.743(2) \AA, \boldsymbol{c}=25.346(6) \AA)$, volume $\left.1458.76(5) \AA^{3}\right), \boldsymbol{Z}=8$ ). The asymmetric unit cell consists of a combination of $[\mathrm{Cd} 0.5$ $\left.\mathrm{Cl}_{3}\right]^{-}$anions, one organic ${ }^{+} \mathrm{NH}_{3}\left(\mathrm{CH}_{2}\right) \mathrm{CO}_{2} \mathrm{H}$ cations, and one water molecule to form a twodimensional perovskite system. The hydrogen-bonding network ensures cohesion between these layers. The micro-Raman spectroscopy measurement technique is used to probe organic-inorganic halide perovskite vibration modes. The compound was, also, characterised using the vibrating sample magnetometer VSM and the UV-visible absorption techniques.
\end{abstract}

Keywords: Organic-inorganic hybrid, X-ray diffraction, Crystal structure, Micro-Raman spectroscopy, Vibrating sample magnetometer

*Corresponding author:

E-mail address: a.kaiba@psau.edu.sa (A. Kaiba)

Address: Department of Physics, College of Science and Humanities in Al-Kharj, Prince Sattam bin Abdulaziz

University, Al-Kharj 11942, Saudi Arabia 


\section{Introduction}

Organic-inorganic layered perovskite compounds have been studied for over 80 years. These compounds are a sub-family of perovskites $\mathrm{AMX}_{3}$ structure, where $\mathrm{A}$ is an organic cation, $\mathrm{M}$ is a divalent ion which can be $\mathrm{Pb}^{2+}, \mathrm{Cu}^{2+}, \mathrm{Sn}^{2+}, \mathrm{Co}^{2+}, \mathrm{Fe}^{2+}, \mathrm{Mn}^{2+}, \mathrm{Cr}^{2+}, \mathrm{Cd}^{2+}$, or $\mathrm{Yb}^{2+}$ and $\mathrm{X}$ is an oxygen atom in the case of oxides but it can be halogen or nitrogen in other cases; note that the electronegative atom is in its ionic form (halide) [1-3]. Many studies have been published with the formula $\left[\mathrm{R}-\mathrm{NH}_{3}\right]_{2} \mathrm{MCl}_{4}$. Remy et al synthesised a series of compounds containing copper chloride and short alkyl chains with amino groups [4]. The organic-inorganic hybrids have received considerable interest in the recent years as they present unique thermal, magnetic, electronic, and optical properties offering opportunities for many technological applications. Most of the layered organic-inorganic hybrid materials have perovskite-type structures, where inorganic sheets consist of corner-sharing $\mathrm{MX}_{6}$ octahedral or tetrahedral as for Zinc and cobalt.

The ammonium function allows the organic molecule to be inserted between the octahedra, with ionic bonds between $\mathrm{NH}_{3}{ }^{+}$and $\mathrm{X}^{-}$, which ensures the cohesion of the molecular crystal. There are two possible scenarios: one hydrogen atom can bond to the bridging halide and two hydrogen atoms to the terminal halides (terminal halogen configuration) or vice versa with two bridging and terminal hydrogen atoms (bridging halogen configuration). Various studies of organicinorganic hybrids based on ammonium chains with the general formula $\left[\left(\mathrm{C}_{\mathrm{n}} \mathrm{H}_{2 \mathrm{n}+1} \mathrm{NH}_{3}\right)_{2} \mathrm{MX}_{4}\right]$ ( $\mathrm{n}=1-18 ; \mathrm{X}=\mathrm{Cl}, \mathrm{Br}, \mathrm{I} ; \mathrm{M}=\mathrm{Cd}^{2+}, \mathrm{Mn}^{2+} \ldots$ ) have been published [5-8].

This family of compounds has a wide set of structures, properties, and applications; notably, some hybrids are used in solar energy storage field and photovoltaic cells. The first approved cell with an efficiency of $12 \%$ was manufactured; its performance increased rapidly and reached $20 \%$ in 2014 [9-11]. The challenge now is to develop photovoltaic cells using chemical methods that are inexpensive, reduce manufacturing time, and have a high conversion efficiency [12]. Currently, the photovoltaic devices based on $\mathrm{PbI}_{3} \mathrm{CH}_{3} \mathrm{NH}_{3}$, which is a combination of lead halide and short chain (methylamine), present an unprecedentedly rapid rise in energy conversion efficiency. Theses composites with short organic chains provided the highest energy conversion efficiency [13-19]. In this context, the layered organic inorganic hybrid like perovskite systems are an important family of functional materials. Among them those based on copper and cadmium halides have been widely studied due to their fascinating structures and versatile applications in solar energy, display devices, probes of biological systems. Particularly, cadmium halide based on organic inorganic hybrids have shown numerous attractive properties, such as 
photoluminescence, optical, electrical and catalytic properties. The combination of cadmium halide and organic cations have been previously highlighted [20-24]. The first reported organicinorganic layered perovskite-type hybrids with carboxylic dimers were [( $\beta$-aluminium $\left.)_{2} \mathrm{CuCl}_{4}\right]$ and $\left[(\beta \text {-aluminium })_{2} \mathrm{CuBr}_{4}\right]$ [25]. Other composites, $\left[\left(\mathrm{HO}_{2} \mathrm{C}\left(\mathrm{CH}_{2}\right)_{3} \mathrm{NH}_{3}\right)_{2} \mathrm{Pbl}_{4}\right]$ and $\left[\left(\mathrm{NH}_{3}-\right.\right.$ $\left.\left(\mathrm{CH}_{2}\right)_{3}-\mathrm{CO}_{2} \mathrm{H}\right)_{2} \mathrm{CdCl}_{4}$ ], were also studied [26]. In this work, glycine $\left(\mathrm{NH}_{2}-\mathrm{CH}_{2}-\mathrm{CO}_{2} \mathrm{H}\right)$ considered as the organic moiety was combined to cadmium chloride considered as the inorganic moiety to prepare the $\left[\mathrm{NH}_{3}-\mathrm{CH}_{2}-\mathrm{COOH}\right] \mathrm{CdCl}_{3} \cdot \mathrm{H}_{2} \mathrm{O}$ composite. Glycine is a short chain amino acid ligand that substituted the commonly used monoamines such as methyl amines. The main purpose of this study is to investigate the structural, spectroscopic, magnetic and optical properties at room temperature of the synthesised composite.

\section{Experimental Section}

Single crystals of $\left[\mathrm{NH}_{3}-\mathrm{CH}_{2}-\mathrm{COOH}\right] \mathrm{CdCl}_{3} \cdot \mathrm{H}_{2} \mathrm{O}$ were obtained as follows: a solution of glycine $(1 \mathrm{~g}$, $13.3 \mathrm{mmol}$ ) in distilled water was prepared and protonated by $1 \mathrm{~mL}$ of hydrochloric acid (37\%) added dropwise. The protonated solution was added dropwise to a solution of cadmium chloride $(1.34 \mathrm{~g}, 6.7$ mmol) in distilled water. The transparent reaction mixture was stored at room temperature. The single crystals suitable for X-ray diffraction, were obtained after a for several days.

To evaluate the purity of the compound, X-ray photoelectron spectroscopy (XPS) analyses were performed using the K-Alpha XPS System (Thermo Fisher Scientific) equipped with a microfocused monochromatic Al Ka X-ray source (1486.6 eV). Raman spectroscopy investigations were performed using a SENTERRA II Compact Raman Microscope (Brucker) with a wavelength of $532 \mathrm{~nm}$ (green laser) and power of $0.25 \mathrm{~mW}$ in the wavelength range 50-4000 $\mathrm{cm}^{-1}$. The optical absorbance was recorded on a JASCO V-570 instrument within the range of 200-800 nm.

A scanning electron microscope (Quanta FEG 250) was used to determine the grain morphology

of this compound. The magnetic measurements were recorded at room temperature using a vibrating sample magnetometer (EZ7; MicroSense) with a maximum applied field of $5 \mathrm{kOe}$. A regular single crystal was selected using an optical microscope. The Powder XRD Ultima IV Xray Diffractometer equipped with conventional X-ray source $\mathrm{Cu} K \alpha$ radiation (1: $1.54056 \AA$ ) was used to performed X-ray diffraction pattern with a $2 \theta$ range of 5-60 . A Nonius_Kappa_CCD diffractometer with a molybdenum anticathode was used for full data collection. The $\phi$ and $\omega$ scan modes were used, with a crystal-detector distance of $40 \mathrm{~mm}$. The degree of mosaicity was 
$\left(0.35^{\circ}\right)$. DENZO-SMN program was used to reduce the data. The SIR 97 program allowed us to have a structural hypothesis [27], and SHELX 97 allowed us to refine all the atomic parameters using the full-matrix least-squares technique on squared structure factor $\mathrm{F}^{2}$ [28]. Hydrogen atoms were located theoretically and refined isotropically. All these programs were used within the WINGX package [29]. The DIAMOND [30] and MERCURY [31] programs were used for all the graphics. All the structural data in the Cambridge crystallographic data center Nos. CCDC 1985794 and can also be obtained freely at www.ccdc.cam.ac.uk/data_request/cif.

\section{Results and Discussion}

\subsection{X-ray diffraction studies}

The powder X-ray diffraction (PXRD) experiment was carried out to confirm the good crystallinity and homogeneity of the synthesized product $\left[\mathrm{NH}_{3}-\mathrm{CH}_{2}-\mathrm{COOH}\right] \mathrm{CdCl}_{3} \cdot \mathrm{H}_{2} \mathrm{O}$.

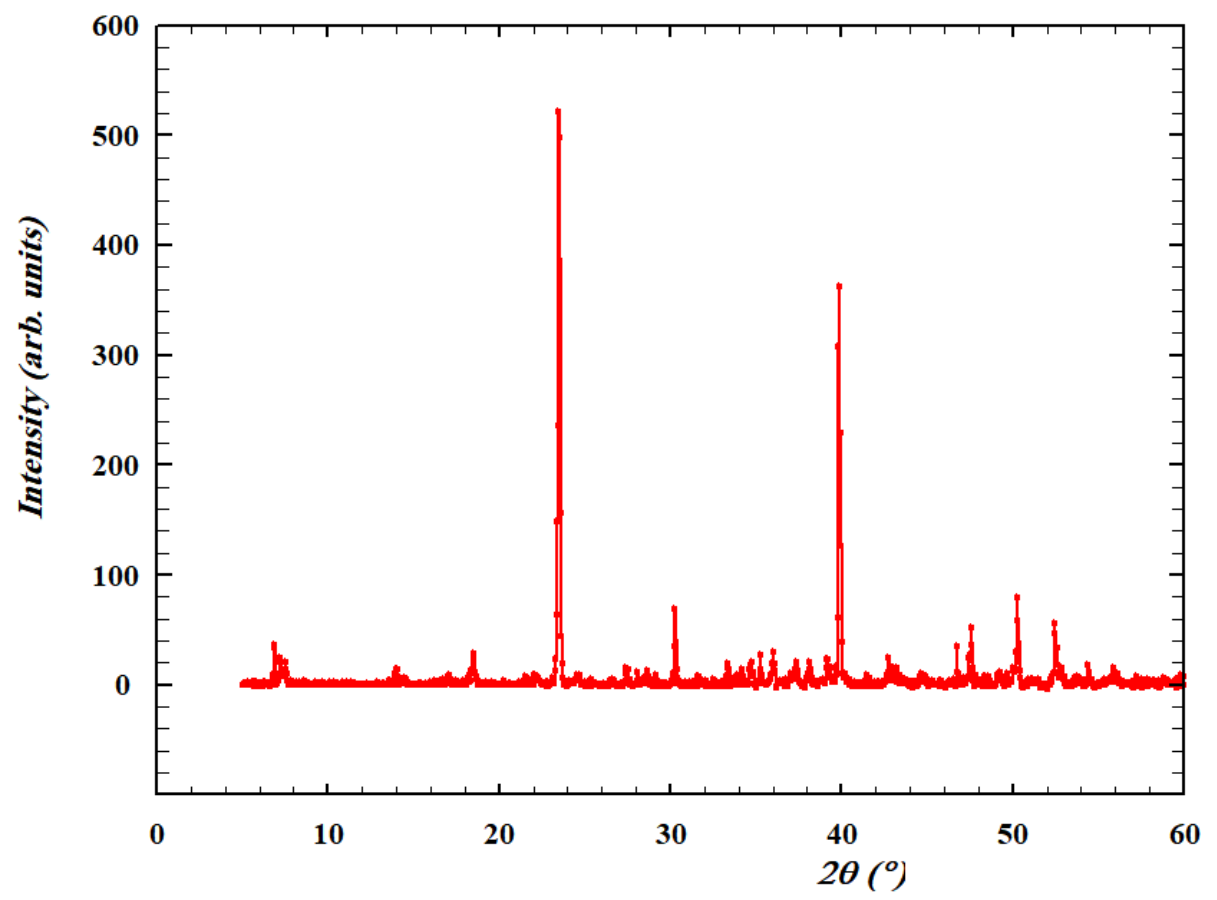

Figure 1: experimental powder XRD patterns synthesized product $\left[\mathrm{NH}_{3}-\mathrm{CH}_{2}-\right.$ $\mathrm{COOH}] \mathrm{CdCl}_{3} \cdot \mathrm{H}_{2} \mathrm{O}$

The structure of the titled compound was solved at room temperature. The results of data measurements and refinement are summarised in Table 1. The SXRD study was performed at room temperature and reveals that this compound crystalizes in an orthorhombic system with a Pcam space group, $\boldsymbol{a}=7.433(10) \AA, \boldsymbol{b}=7.743(2) \AA ⿻$ 的 $=25.346(6) \AA$ ), volume $1458.76(5) \AA^{3}$ ) 
and $\boldsymbol{Z}=8$ parameters. The asymmetric unit contains one cation ${ }^{+} \mathrm{NH}_{3}-\left(\mathrm{CH}_{2}\right)-\mathrm{COOH}$, one anion $\left[\mathrm{CdCl}_{3}\right]^{-}$, and one $\mathrm{H}_{2} \mathrm{O}$ molecule (Fig. 2a). In this structure, three general positions are occupied by cadmium and two equatorial chloride ions with a refined occupancy factor 0.5 (Site Occupation Factor SOF $=0.5)$. The site occupation factor $(\mathrm{SOF})$ gives the probability to find an atom at a specific site. Its value ranges from nearly 0 (no atom) to a maximum of 1 (100\%, site always occupied by this atom). The location that are not occupied are voids. In solids compounds, these can occur so that the charge on ions can be balanced [32].

This partial occupancy is a type of disorder encountered during the analysis of the crystal structure.

Moreover, the crystal structure is built by alternating between organic and inorganic parts stacked along the $c$-axis. The inorganic part consists of $\mathrm{CdCl}_{6}$ octahedrons linked with each other by chlorine atoms (Fig. 2b); the cohesion is ensured by hydrogen interactions. The hydrogen bond involves N-H...Cl connections established between the organic and inorganic layers (Fig. 2d) along with the first scenario (one hydrogen atom can bond to the bridging halide and two hydrogen atoms to the terminal halides (terminal halogen configuration), where the $\mathrm{NH}-\mathrm{Cl}$ distances $\left(\mathrm{Cl}_{\text {axial }}, \mathrm{Cl}_{\text {axial, }}\right.$ and $\left.\mathrm{Cl}_{\text {equatorial }}\right) 2.368,2.467$, and $2.507 \AA$, respectively. Moreover, the second type of hydrogen bond interactions $\left({ }^{+} \mathrm{NH}_{3}\left(\mathrm{CH}_{2}\right) \mathrm{COOH} \ldots \mathrm{H}_{2} \mathrm{O}\right)$ is formed between the acid function and three molecules of $\mathrm{H}_{2} \mathrm{O}$ with distances ranging between $1.800 \AA$ and $3.030 \AA$ (Figs. 2c, 2d). There is another type of hydrogen bond interaction between the octahedron and $\mathrm{H}_{2} \mathrm{O}$ molecule $\left(\mathrm{CdCl}_{6} \ldots . \mathrm{H}_{2} \mathrm{O}\right)$, separated by about $2.616 \AA$ (Fig. 2d). Indeed, $\mathrm{H}_{2} \mathrm{O}$ molecules play crucial role to ensure the cohesion of this compound. It is obvious that hydrogen bond interactions have an important effect on the stabilization of the packing in the crystal structure. Despite complex hydrogen bond network, no twisted conformations of the organic chains are noted. The torsion angle $\mathrm{NCCO}$ is about $172^{\circ}$.

The coordination geometry around $\mathrm{Cd}(\mathrm{II})$ is a distorted octahedron. Each Cd atom is coordinated by six chlorides, in which four chlorides occupy the basal plane while two chlorides occupy axial positions. The average $\mathrm{Cd}-\mathrm{Cl}$ distances for the $\left[\mathrm{CdCl}_{6}\right]$ octahedron for other $\mathrm{Cd}(\mathrm{II})$ salts, found in the Cambridge structural database (CSD), range between $2.45 \AA$ and $2.47 \AA$ [33]. However, for this compound the $\mathrm{Cd}-\mathrm{Cl}$ distances lie between 2.520 and $3.061 \AA$, the $\mathrm{Cl}-\mathrm{Cd}-\mathrm{Cl}$ angle values are between $82.99^{\circ}$ and $100.28^{\circ}$ and the bridging angles $\mathrm{Cd}-\mathrm{Cl}-\mathrm{Cd}$ are $147^{\circ}$ and $164.01^{\circ}$ (Table 2). The distance between neighbouring $\mathrm{Cd}$... Cd in the inorganic sheet is $5.077 \AA$ and $5.672 \AA$. In 
addition, the organic sheets display an alternation between long and short bonds $\mathrm{Cd}-\mathrm{Cl}$ ( 2.666 and $3.061 \AA$ ) along with a non-linear bridging Cd-Cl-Cd angle (Fig. 2e). The distortion angle parameter $\sum$, referred to as the sum of all the deviations from $90^{\circ}$ of the 12 cis $\Phi$ angles in the co-ordination sphere, is often used to estimate the coordination-sphere distortion [34]. Herein, $\Sigma$ $\left(55.5^{\circ}\right)$ shows a significantly hard distortion of the co-ordination spheres of $\mathrm{CdCl}_{6}$ with respect to similar compound such as $\left[\mathrm{NH}_{3}-\left(\mathrm{CH}_{2}\right)_{3}-\mathrm{COOH}\right]_{2} \mathrm{CdCl}_{4} ;\left(\sum=15.8^{\circ}\right)$ [26]. This strong distortion of the octahedron $\mathrm{CdCl}_{6}$ is caused by the hydrogen bonds interactions of the ligand ${ }^{+} \mathrm{NH}_{3}-\mathrm{CH} 2$ $\mathrm{COOH}$ via ${ }^{+} \mathrm{NH}_{3}$ group and the $\mathrm{H}_{2} \mathrm{O}$. Moreover, the interlayer spacing between two adjacent inorganic layers $\left(d_{I n t}=12.672 \AA\right.$ ) (Fig. $\left.2 \mathrm{~b}\right)$ was found to be less than the interlayer distance of $\left[\mathrm{NH}_{3}-\left(\mathrm{CH}_{2}\right)_{3}-\mathrm{COOH}\right]_{2} \mathrm{CdCl}_{4}\left(\mathrm{~d}_{\mathrm{Int}}=15.6 \AA\right)$.

Table 1: X-ray diffraction and crystal data of the organic-inorganic hybrid $\left[\mathrm{NH}_{3}-\mathrm{CH}_{2}\right.$ $\mathrm{COOH}] \mathrm{CdCl}_{3} \cdot \mathrm{H}_{2} \mathrm{O}$

\begin{tabular}{|c|c|}
\hline Crystal data & $\mathrm{C}_{2} \mathrm{H}_{6} \mathrm{Cd}_{0.5} \mathrm{Cl}_{2} \mathrm{NO}_{3}$ \\
\hline $\begin{array}{l}\text { Volume } \\
Z \\
\text { Density (calculated) } \\
\text { Absorption coefficient } \\
\text { F(000) } \\
\text { Crystal size } \\
\text { Theta range for data collection } \\
\text { Index ranges } \\
\text { Reflections collected } \\
\text { Independent reflections } \\
\text { Completeness to theta = 25.242 } \\
\text { Refinement method } \\
\text { Data / restraints / parameters } \\
\text { Goodness-of-fit on F }{ }^{2} \\
\text { Final R indices [I>2sigma(I)] } \\
\text { R indices (all data) } \\
\text { Largest diff. peak and hole }\end{array}$ & $\begin{array}{l}\mathrm{C}_{2} \mathrm{H}_{8} \mathrm{Cd}_{0.50} \mathrm{Cl}_{2} \mathrm{~N} \mathrm{O}_{3} \\
221.19 \\
293(2) \mathrm{K} \\
0.71073 \AA \\
\text { Orthorhombic } \\
\text { Pc a m } \\
\mathrm{a}=7.43290(10) \AA \quad \alpha=90^{\circ} . \\
\mathrm{b}=7.7433(2) \AA \quad \quad \beta=90^{\circ} . \\
\mathrm{c}=25.3463(6) \AA \quad \gamma=90^{\circ} . \\
1458.81(5) \AA^{-3} \\
8 \\
2.014 \mathrm{Mg}^{-3} \mathrm{~m}^{3} \\
2.244 \mathrm{~mm}^{-1} \\
872 \\
0.17 \times 0.14 \times 0.12 \mathrm{~mm}^{3} \\
2.630 \text { to } 26.346^{\circ} . \\
-9<=\mathrm{h}<=9,-9<=\mathrm{k}<=9,-31<=1<=31 \\
2759 \\
1525[\mathrm{R}(\text { int })=0.0225] \\
99.7 \% \\
\text { Full-matrix least-squares on } \mathrm{F}^{2} \\
1525 / 10 / 75 \\
1.047 \\
\mathrm{R} 1=0.0275, \text { wR2 }=0.0673 \\
\mathrm{R} 1=0.0338, \text { wR2 }=0.0700 \\
0.549 \text { and }-0.866 \text { e. } \AA^{-3}\end{array}$ \\
\hline
\end{tabular}



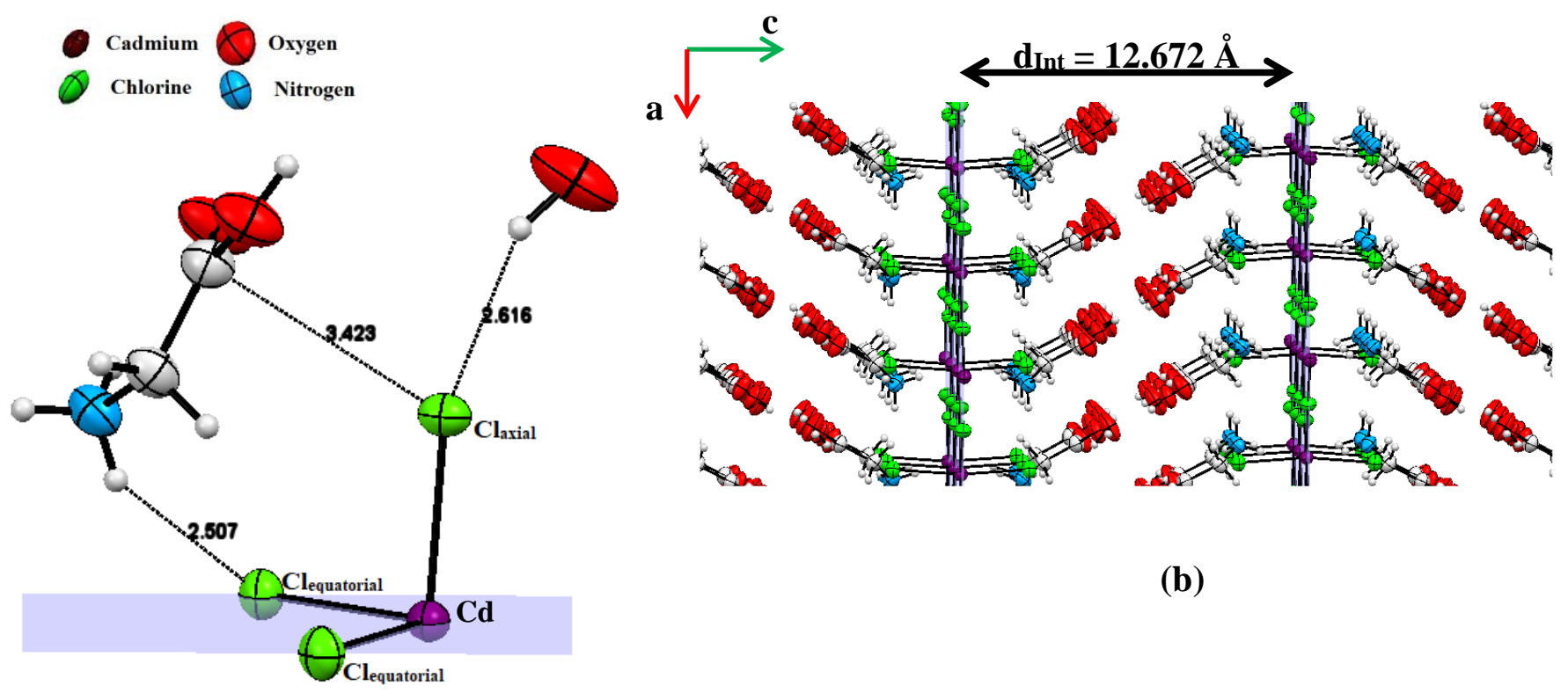

(b)

(a)
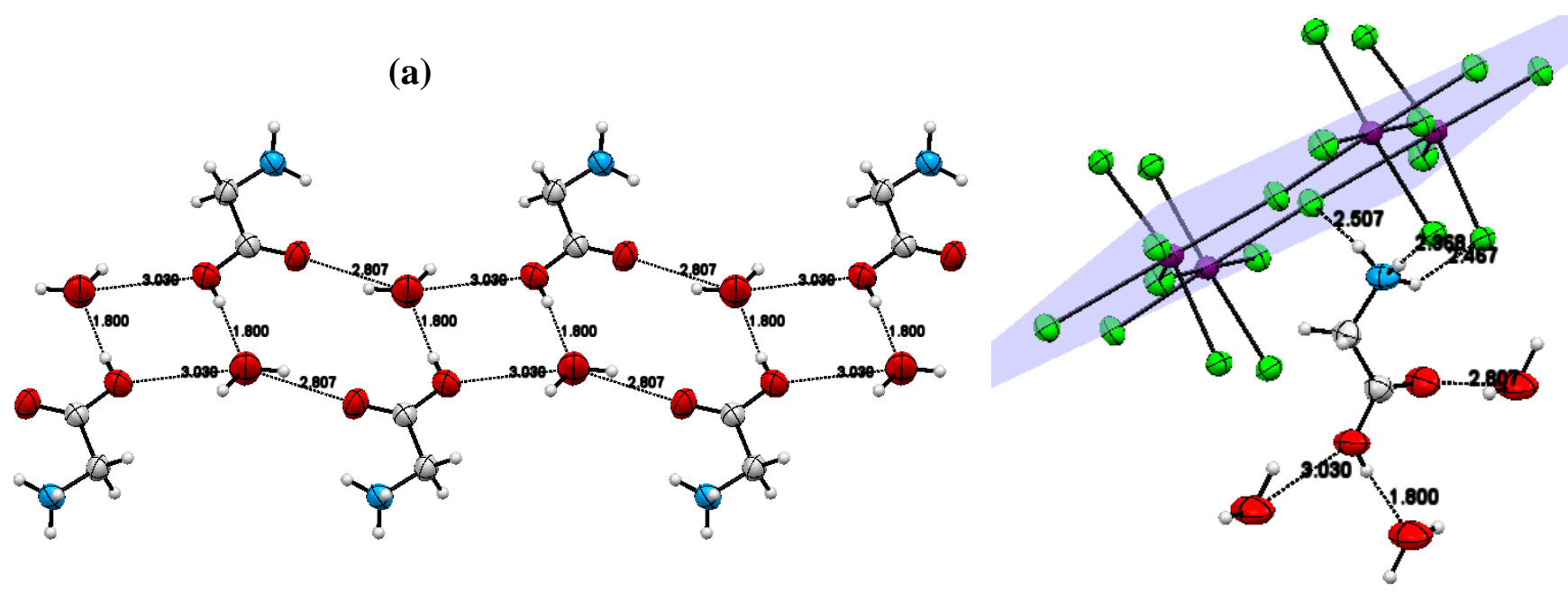

(c)

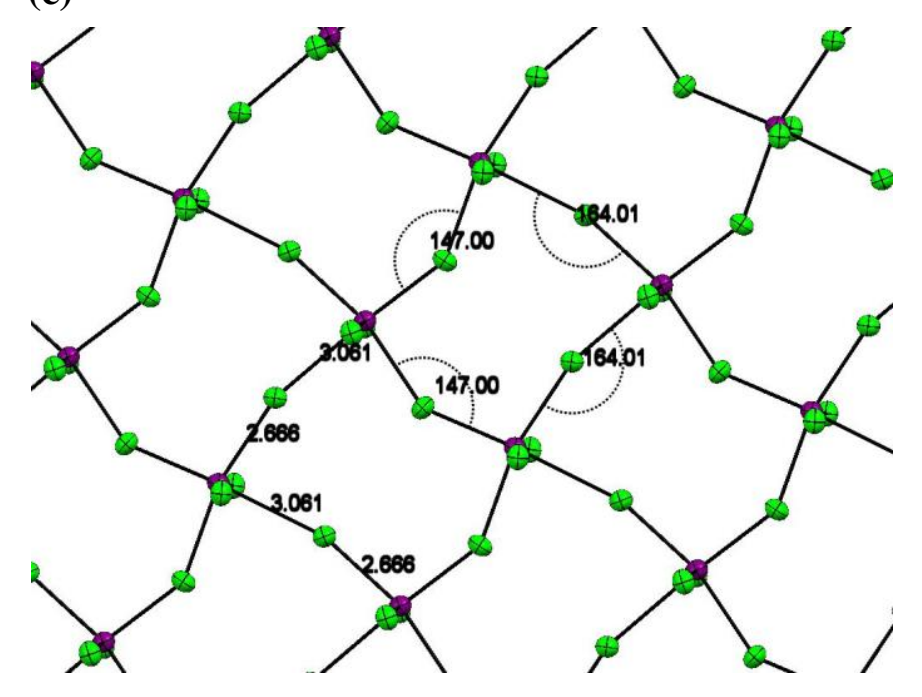

(d)

(e) 
Figure 2. View showing the asymmetric unit (a). Crystal packing along the b-axis, clearly showing the alternation between the organic and inorganic layers along the c-axis (b). Connection between the organic chains and water by $\mathrm{OH} \ldots \mathrm{H}_{2} \mathrm{O}$ hydrogen bonds (dashed lines) (c). Cohesion between the organic and inorganic chains by N-H...Cl hydrogen bonds and organic chain and three $\mathrm{H}_{2} \mathrm{O}$ molecules (dashed lines) (d). View showing bridging angles $\mathrm{Cd}-\mathrm{Cl}-\mathrm{Cd}$ and alternation of long and short bonds $\mathrm{Cd}-\mathrm{Cl}$ in inorganic sheet (e).

Table 2: Bond lengths $[\AA]$ and angles $\left[^{\circ}\right]$ for octahedral $\left[\mathrm{CdCl}_{6}\right]$ of the organic-inorganic hybrid $\mathrm{C}_{2} \mathrm{H}_{6} \mathrm{Cd}_{0.5} \mathrm{Cl}_{2} \mathrm{NO}_{3}$

\begin{tabular}{|c|c|c|c|}
\hline Bond lengths Cd-Cl $[\AA \mathbf{A}]$ & \multicolumn{2}{|c|}{ Angles Cl-Cd-Cl ${ }^{\circ}{ }^{\circ}$} & Angles Cd-Cl-Cd $\left[^{\circ}{ }^{\circ}\right.$ \\
\hline 2.520 & 88.49 & 96.2 & 147 \\
2.520 & 90.01 & 96.2 & 164.01 \\
2.666 & 90.01 & 100.28 & \\
2.697 & 88.49 & 82.99 & \\
2.598 & 83.74 & 83.26 & \\
3.061 & 83.74 & 93.48 & \\
\hline
\end{tabular}

\subsection{X-ray photoelectron spectroscopy (XPS) analysis}

The purity of the prepared compound was examined by using XPS. The XPS survey scan (Fig 3) reveals the existence of characteristic peaks assigned to carbon, oxygen, cadmium, chloride, and nitrogen. The main peaks are $\mathrm{O}_{1 \mathrm{~s}}, \mathrm{Cd}_{3 \mathrm{~d}}, \mathrm{~N}_{1 \mathrm{~s}}, \mathrm{C}_{1 \mathrm{~s}}$ and $\mathrm{Cl}_{2 \mathrm{p}}$ centred at $533 \mathrm{eV}, 406 \mathrm{eV}, 400 \mathrm{eV}, 288$ $\mathrm{eV}$ and $201 \mathrm{eV}$ respectively. The atomic percentage is about $42 \%$ for carbon, $24.5 \%$ for oxygen, $11.5 \%$ for nitrogen, $17 \%$ for Chlorine and $5 \%$ for cadmium, $\%$ which emphasising the purity of our compound. 


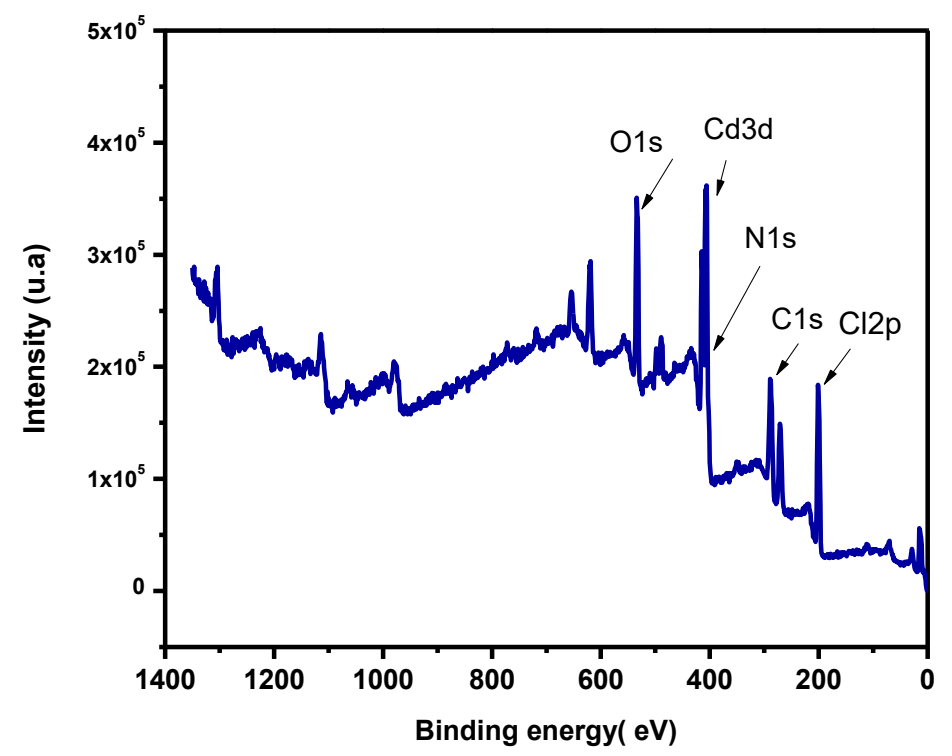

Figure 3: The whole XPS spectrum of $\left[\mathrm{NH}_{3}-\mathrm{CH}_{2}-\mathrm{COOH}\right] \mathrm{CdCl}_{3} \cdot \mathrm{H}_{2} \mathrm{O}$

\subsection{Scanning Electron Microscopy}

Morphologic investigations of $\left[\mathrm{NH}_{3}-\mathrm{CH}_{2}-\mathrm{COOH}\right] \mathrm{CdCl}_{3} \cdot \mathrm{H}_{2} \mathrm{O}$ were performed by scanning electron microscopic (Fig4). The recorded image displays single crystal of foliated-like structure as well as several crystal fragments having uniform distribution and a flat surface which indicates good crystal quality [24, 35], this confirms the 2D perovskite structure consists of metallic layers parallel to the ab-plane, obtained by corner sharing between octahedra built of cadmium(II) cations surrounded by six chloride anions.

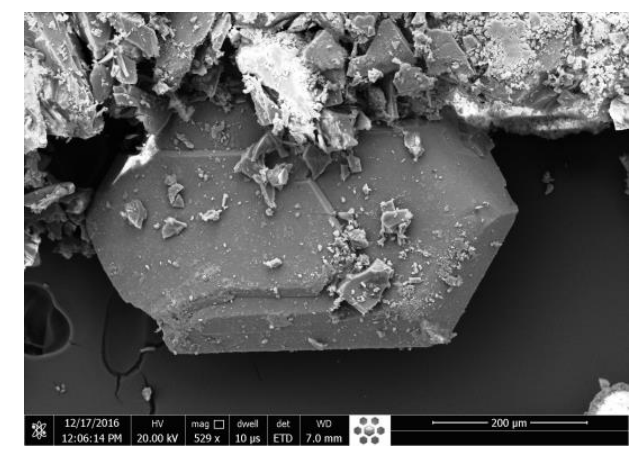

Figure.4: SEM micrograph of $\left[\mathrm{NH}_{3}-\mathrm{CH}_{2}-\mathrm{COOH}\right] \mathrm{CdCl}_{3} \cdot \mathrm{H}_{2} \mathrm{O}$ 


\subsection{Raman Analysis}

Raman spectroscopy, as a local and sensitive technique, is usually used to gather information about crystallinity. Spectrum were carried out with green laser $\lambda=352 \mathrm{~nm}$ and at $\mathrm{P}=0.25 \mathrm{~mW}$. Typical Raman spectrum of $\left[\mathrm{NH}_{3}-\mathrm{CH}_{2}-\mathrm{COOH}\right] \mathrm{CdCl}_{3} \cdot \mathrm{H}_{2} \mathrm{O}$ is shown in figure 5. The analysis of the spectrum reveals that the vibrational spectra of the amino acid metal halide category of hybrid compounds can be divided into two regions. The region below $400 \mathrm{~cm}^{-1}$ associated with the internal modes of crystal including the distorted $\mathrm{CdCl}_{6}$ octahedron vibrations as shown in structural part. Indeed, the bands located at $62 \mathrm{~cm}^{-1}$ and $143 \mathrm{~cm}^{-1}$ are assigned to the symmetric and asymmetric bending modes of the $\mathrm{Cl}-\mathrm{Cd}-\mathrm{Cl}$ in equatorial plan symmetry. While the stretching mode symmetric of the $\mathrm{Cd}-\mathrm{Cl}$ bonds is observed at $243 \mathrm{~cm}^{-1}[36,37]$.

Above $400 \mathrm{~cm}^{-1}$ the Raman active modes are associated to stretching modes of the amino acid cation. Specifically, the C-N and C-H stretching modes in the range $1000-1050 \mathrm{~cm}^{-1}$; the symmetric and antisymmetric NH bending in the range 1350-1800 $\mathrm{cm}^{-1}$; and symmetric and asymmetric NH stretching in the range $3000-3200 \mathrm{~cm}^{-1}$. The bands located at 443, 609 and 853 $\mathrm{cm}^{-1}$ are characteristic respectively to twisting mode of $\mathrm{NH}_{3}$ groups, $\mathrm{C}-\mathrm{CO}$ in plane deformation vibration and rocking vibration of $\mathrm{CH}_{2}$. The stretching vibration of $\mathrm{OH}$ is located at $899 \mathrm{~cm}^{-1}$. The C-C skeletal vibrations and the C-N stretching vibrations are observed at 1089 and $1105 \mathrm{~cm}^{-}$ ${ }^{1}$, while the bands located at 1306 and $1325 \mathrm{~cm}^{-1}$ are assigned to rocking vibration of $\mathrm{NH}_{3}$ group and $\mathrm{O}-\mathrm{H}$ deformation vibration. The band observed at $1418 \mathrm{~cm}^{-1}$ is assigned to deformation vibration of $\mathrm{CH}_{2}$. Furthermore, different modes due to $\mathrm{N}-\mathrm{H} . . . \mathrm{Cl}$ hydrogen bonds and to the torsional motion of molecular subunits are observed. Symmetric and asymmetric stretching vibrations of the $\mathrm{O}-\mathrm{H}$ bond are shown at 2966 and $3160 \mathrm{~cm}^{-1}$ [38-41].

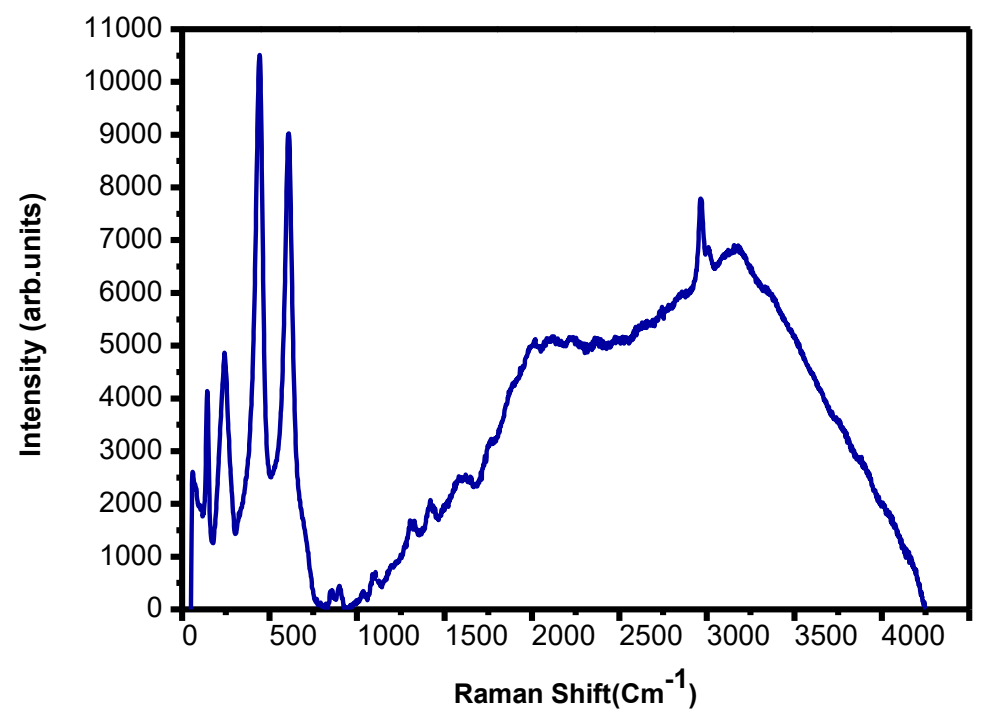


Figure 5. Raman spectrum of $\left[\mathrm{NH}_{3}-\mathrm{CH}_{2}-\mathrm{COOH}\right] \mathrm{CdCl}_{3} \cdot \mathrm{H}_{2} \mathrm{O}$, with green laser $532 \mathrm{~nm}$ at $\mathrm{P}=$ $0.25 \mathrm{~mW}$

\subsection{VSM magnetization curve.}

VSM analysis was performed to evaluate the magnetic property of $\left[\mathrm{NH}_{3}-\mathrm{CH}_{2}-\mathrm{COOH}\right] \mathrm{CdCl}_{3} . \mathrm{H}_{2} \mathrm{O}$ at room temperature. A ferromagnetic hysteresis loop can be clearly seen in Figure 5. Therefore, this compound exhibits a ferromagnetic behaviour with a remnant magnetisation $\mathrm{Mr}$ of approximately $2 \times 10^{-4} \mathrm{emu}_{\mathrm{g}} \mathrm{g}^{-1}$ and coercive field, referred to as as the reverse field needed to drive the magnetisation to zero after saturation, $H c=334 \mathrm{Oe}$. The magnetic saturation $M_{s}$ is approximately $6.33 \times 10^{-4} \mathrm{emu}^{-\mathrm{g}^{-1}}$. Generally, in organic-inorganic hybrids, magnetism arises from the metal-ions transition in the inorganic moieties [42]. Even if, the copper is diamagnetic transition metal, it's become paramagnetic when present in compound. $\mathrm{Cu}(\mathrm{II})$ salts exhibit a strong Jahn-Teller distortion in $\left[\mathrm{MX}_{6}\right]$ octahedra, with antiferrodistortive arrangement of the molecular axes in the plane of the perovskite sheet which leads to ferromagnetic interactions [43]. The Jahn-Teller distortion appearing in copper-based hybrids, where the alternation of long and short bonds due to Jahn-Teller effect leads to cooperative antiferro-distortive arrangements of the neighbouring octahedra, producing, hence, ferromagnetic interactions so that the spins become ferromagnetically ordered [44-46]. The five $\mathrm{d}$ atomic orbitals are split into two degenerate sets when constructing a molecular orbital diagram. These are represented by the sets' symmetry labels: $t_{2 g}\left(d_{x z}, d_{y z}, d_{x y}\right)$ and $e_{g}\left(d z^{2}\right.$ and $\left.d_{x^{2}}-y^{2}\right)$. When a molecule possesses a degenerate electronic ground state, it will distort to remove the degeneracy and form a lower energy (and by consequence, lower symmetry) system. The octahedral complex will either elongate or compress the $\mathrm{z}$ ligand bonds. The cadmium $\mathrm{Cd}^{2+}\left(\mathrm{d}^{10}\right)$ belong to the case of transition metal ion in octahedral coordination the electronic configurations $\left(\mathrm{d}^{3}, \mathrm{~d}^{5}, \mathrm{~d}^{8}\right.$, and $\left.\mathrm{d}^{10}\right)$ do not exhibit Jahn-Teller distortions, even if the $\mathrm{CdCl}_{6}$ octahedron present significantly hard distortion $\left(\sum=55.5^{\circ}\right)$ as seen in structural description. As known cadmium transition metal is diamagnetic, but this $2 \mathrm{D}\left[\mathrm{NH}_{3}-\mathrm{CH}_{2}-\mathrm{COOH}\right] \mathrm{CdCl}_{3} \cdot \mathrm{H}_{2} \mathrm{O}$ compound exhibit unusual ferromagnetic behaviour at room temperature (Figure 6). This let us think that there is presence of paramagnetic impurities. This hypothesis is exclude because the XPS technique has shown that our compound is pure. The compound present a disorder in the level of the distorted $\mathrm{CdCl}_{6}$ octahedron caused by partial occupancy of atoms (Site Occupation Factor SOF $=0.5$ for cadmium and equatorial chloride see 
structural part above). In this compound these can occur so that the charge on ions can be balanced.

The distortion and the partial occupancy let us think that $\mathrm{Cd}^{2+}\left(\mathrm{d}^{10}\right)$ (diamagnetic has been reduced to $\mathrm{Cd}^{+}\left(\mathrm{d}^{9}\right)$ which is paramagnetic, this allowed the compression of $\mathrm{CdCl}_{6}$ octahedron similar to Jahn - Teller distortion. So, the magnetism behaviour seems to originate from $\mathrm{Cd}^{+}$ ions. In fact, it here is super-exchange interactions between neighbouring $\mathrm{Cd}^{+}$ions via no linear pathways $\mathrm{Cd}-\mathrm{Cl}-\mathrm{Cd}\left(147^{\circ}\right.$ and $\left.167.01^{\circ}\right)$. This interaction is mediated by the non-magnetic chlorine ion, with a key role in the magnetic properties. Actually, the compound showed significantly hard distortion in the level of the co-ordination spheres $\mathrm{CdCl}_{6}$ giving rise to changes in the $\mathrm{Cd}-\mathrm{Cl}$ bond lengths and alternation of long and short bonds ( $\mathrm{Cd}-\mathrm{Cl})$. As known, the magnitude of the distortion of the octahedron has an effect on the intensity of the super-exchange interaction between ion, further leading to a weak or a strong ferromagnetism [44].

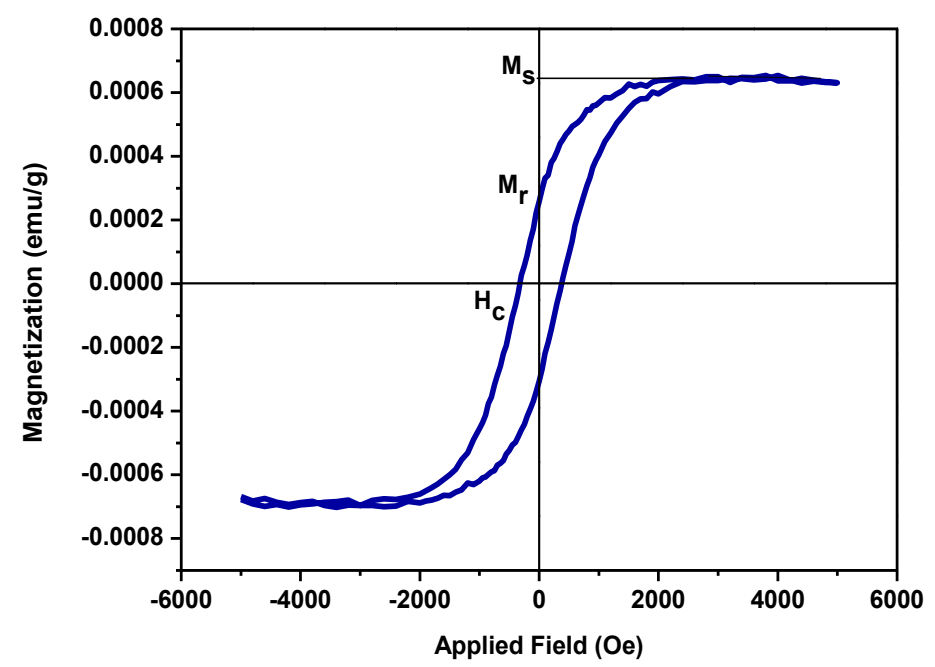

Figure 6: Vibrating sample magnetometer hysteresis loop measurement of $\left[\mathrm{NH}_{3}-\mathrm{CH}_{2}\right.$ $\mathrm{COOH}] \mathrm{CdCl}_{3} \cdot \mathrm{H}_{2} \mathrm{O}$ at room temperature

\subsection{Optical measurements.}

Diffuse absorbance spectroscopy is a technique based on the absorption of light in the ultraviolet/visible light range (Figure 7a). The layered organic-inorganic hybrid $\left[\mathrm{NH}_{3}-\mathrm{CH}_{2}-\right.$ $\mathrm{COOH}] \mathrm{CdCl}_{3} \cdot \mathrm{H}_{2} \mathrm{O}$ show low absorbance (approximately 0.2 arb.units), the absorption edge is 
approximately $527 \mathrm{~nm}$, and the missing absorption are in the wavelengths $575 \mathrm{~nm}$.

Tauc plot method was used to determine the correlation between the absorption coefficient $\alpha(\alpha$ $=2.303 \mathrm{~A} / \mathrm{L}$ ), incident photon energy hv, energy independent constant $\mathrm{k}$, the optical band gap energy $\mathrm{Eg}$, and the exponent $\mathrm{n}$ that represents the nature of transition (direct $\mathrm{n}=2$ and indirect $\mathrm{n}$ $=1 / 2)$. By plotting the $(\alpha h v)^{n}$ versus $(h v)$ for both $n=1 / 2$ and $n=2$, the actual transition type corresponds to the best fit.

The equation $(\alpha h v)^{\mathrm{n}}=\mathrm{k}(\mathrm{hv}-\mathrm{Eg})$, known as the Tauc and Davis-Mott relation, is used to probe the optical band gap energy of $\left[\mathrm{NH}_{3}-\mathrm{CH}_{2}-\mathrm{COOH}\right] \mathrm{CdCl}_{3} \cdot \mathrm{H}_{2} \mathrm{O}$ from the UV/visible spectroscopy (Figure.7b). The estimated energy gap energy equals $2.80 \mathrm{eV}$. Interestingly, the energy gap value of the synthesised compound is lower than that of earlier reported compound $\left[\mathrm{NH}_{3}-\left(\mathrm{CH}_{2}\right)_{3}-\right.$ $\mathrm{COOH}]_{2} \mathrm{CdCl}_{4}(\mathrm{Eg}=3.65 \mathrm{eV})[26]$. The use of a short organic chain $\left(\mathrm{NH}_{2}-\mathrm{CH}_{2}-\mathrm{CO}_{2} \mathrm{H}\right)$ instead of a relatively long chain $\left(\mathrm{NH}_{2}-\left(\mathrm{CH}_{2}\right)_{3}-\mathrm{CO}_{2} \mathrm{H}\right)$ seems to be at origin of this appreciable energy gap value improvement.

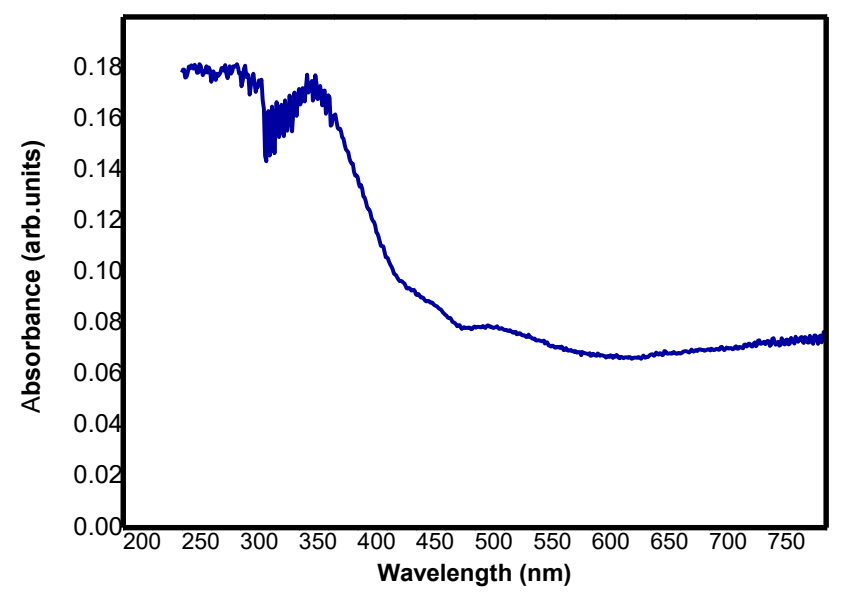

(a)

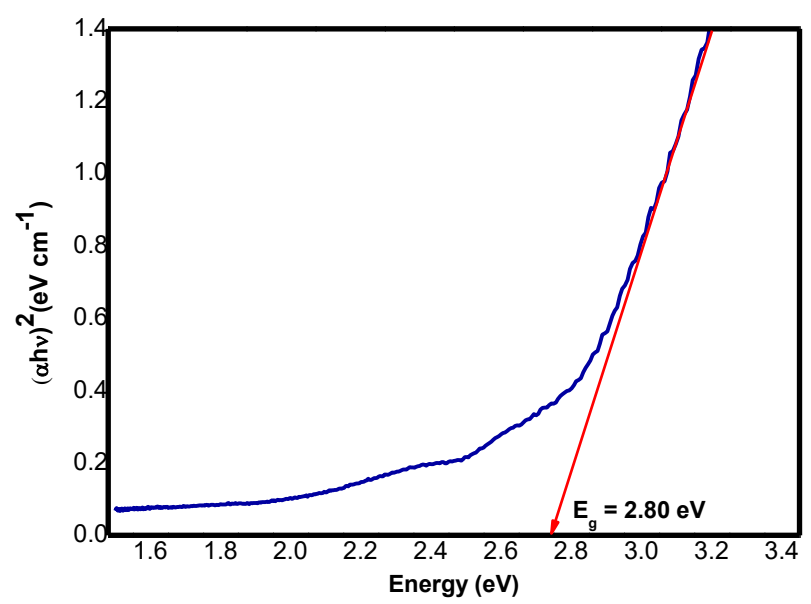

(b)

Figure 7: UV/vis diffuse absorbance plots of $\left[\mathrm{NH}_{3}-\mathrm{CH}_{2}-\mathrm{COOH}\right] \mathrm{CdCl}_{3} \cdot \mathrm{H}_{2} \mathrm{O}$ (a) and tauc plot from the $\mathrm{UV} / \mathrm{Vis}$ analysis of $\left[\mathrm{NH}_{3}-\mathrm{CH}_{2}-\mathrm{COOH}\right] \mathrm{CdCl}_{3} \cdot \mathrm{H}_{2} \mathrm{O}(\mathbf{b})$

\section{Conclusion}

A single crystal of new cadmium halide layer perovskite salt $\left[\mathrm{NH}_{3}-\mathrm{CH}_{2}-\mathrm{COOH}\right] \mathrm{CdCl}_{3} \cdot \mathrm{H}_{2} \mathrm{O}$ was synthesised by slow diffusion at room temperature. The formula unit is formed by $\left[\mathrm{Cd}_{0.5} \mathrm{Cl}_{3}\right]^{-1}$, protonated ${ }^{+} \mathrm{NH}_{3}(\mathrm{CH} 2) \mathrm{CO}_{2} \mathrm{H}$ entities, and one $\mathrm{H}_{2} \mathrm{O}$ molecule. The interlayer cohesion is 
stabilised through various hydrogen bond interactions. The compound has an ionic structure in the form of a layered perovskite system. The attribution of the vibrational bands was carried by comparison with the vibration modes frequencies of homologous compounds. The titled compound exhibits a ferromagnetic behaviour at room temperature with remaining magnetisation $\left(2 \times 10^{-4}\right.$ emu.g $\left.{ }^{-1}\right)$, a coercive field approximately $334 \mathrm{Oe}$, and a saturation of approximately 6.33 x $10^{-4}$ emu.g ${ }^{-1}$. The energy gap value obtained from the optical data using Tauc plot method was $2.80 \mathrm{eV}$.

\section{Acknowledgments}

This project was supported by the Deanship of Scientific Research at Prince Sattam Bin Abdul Aziz University under the research project 2019/01/10463.

\section{References}

[1] D.B. Mitzi, K. Chondroudis, C.R. Kagan, Organic-inorganic electronics, IBM journal of research and development 45(1) (2001) 29-45.

[2] N.L. Allan, M.J. Dayer, D.T. Kulp, W.C. Mackrodt, Atomistic lattice simulations of the ternary fluorides AMF3 ( $A=\mathrm{Li}, \mathrm{Na}, \mathrm{K}, \mathrm{Rb}, \mathrm{Cs} ; \mathrm{M}=\mathrm{Mg}$, Ca, Sr, Ba), Journal of Materials Chemistry 1(6) (1991) 1035-1039.

[3] G.C. Papavassiliou, Three-and low-dimensional inorganic semiconductors, Progress in Solid State Chemistry 25(3-4) (1997) 125-270.

[4] H. Remy, G. Laves, Über Chlorokomplexsalze des zweiwertigen Kupfers, Berichte der deutschen chemischen Gesellschaft (A and B Series) 66(3) (1933) 401-407.

[5] A. Lemmerer, D.G. Billing, Synthesis, characterization and phase transitions of the inorganic-organic layered perovskite-type hybrids [( $\mathrm{C} \mathrm{n} 2 \mathrm{n}+1 \mathrm{NH} 3) 2 \mathrm{Pbl} \mathrm{4],} \mathrm{n}=7,8,9$ and 10, Dalton Transactions 41(4) (2012) 1146-1157.

[6] H. Abid, A. Trigui, A. Mlayah, E. Hlil, Y. Abid, Phase transition in organic-inorganic perovskite (C9H19NH3) 2 Pbl2Br2 of long-chain alkylammonium, Results in Physics 2 (2012) 71-76.

[7] P. Vaněk, M. Havrankova, J. Hybler, Phase transitions in (CH3) 4NPbBr3, Solid state communications 82(7) (1992) 509-512.

[8] D.B. Mitzi, P. Brock, Structure and optical properties of several organic- inorganic hybrids containing corner-sharing chains of bismuth iodide octahedra, Inorganic chemistry 40(9) (2001) 2096-2104.

[9] H. Zhou, Q. Chen, G. Li, S. Luo, T.-b. Song, H.-S. Duan, Z. Hong, J. You, Y. Liu, Y. Yang, Interface engineering of highly efficient perovskite solar cells, Science 345(6196) (2014) 542-546.

[10] M.A. Green, A. Ho-Baillie, H.J. Snaith, The emergence of perovskite solar cells, Nature photonics 8(7) (2014) 506.

[11] M.A. Green, T. Bein, Photovoltaics: Perovskite cells charge forward, Nature materials 14 (2015) 559561.

[12] J. Zhang, P. Barboux, T. Pauporté, Electrochemical design of nanostructured ZnO charge carrier layers for efficient solid-state perovskite-sensitized solar cells, Advanced Energy Materials 4(18) (2014) 1400932.

[13] A.M. Leguy, Y. Hu, M. Campoy-Quiles, M.I. Alonso, O.J. Weber, P. Azarhoosh, M. Van Schilfgaarde, M.T. Weller, T. Bein, J. Nelson, Reversible hydration of CH3NH3PbI3 in films, single crystals, and solar cells, Chemistry of Materials 27(9) (2015) 3397-3407. 
[14] Y. Dang, Y. Liu, Y. Sun, D. Yuan, X. Liu, W. Lu, G. Liu, H. Xia, X. Tao, Bulk crystal growth of hybrid perovskite material CH 3 NH 3 Pbl 3, CrystEngComm 17(3) (2015) 665-670.

[15] J.H. Heo, S.H. Im, J.H. Noh, T.N. Mandal, C.-S. Lim, J.A. Chang, Y.H. Lee, H.-j. Kim, A. Sarkar, M.K. Nazeeruddin, Efficient inorganic-organic hybrid heterojunction solar cells containing perovskite compound and polymeric hole conductors, Nature photonics 7(6) (2013) 486.

[16] R. Liu, Hybrid organic/inorganic nanocomposites for photovoltaic cells, Materials 7(4) (2014) 27472771.

[17] Y. Zhao, K. Zhu, Efficient planar perovskite solar cells based on $1.8 \mathrm{eV}$ band gap $\mathrm{CH} 3 \mathrm{NH} 3 \mathrm{PbI} 2 \mathrm{Br}$ nanosheets via thermal decomposition, Journal of the American Chemical Society 136(35) (2014) 1224112244.

[18] G. Peng, X. Xu, G. Xu, Hybrid organic-inorganic perovskites open a new era for low-cost, high efficiency solar cells, Journal of Nanomaterials 2015 (2015).

[19] G.V. Prakash, K. Pradeesh, R. Ratnani, K. Saraswat, M. Light, J. Baumberg, Structural and optical studies of local disorder sensitivity in natural organic-inorganic self-assembled semiconductors, Journal of Physics D: Applied Physics 42(18) (2009) 185405.

[20] A. Thorn, R.D. Willett, B. Twamley, Crystal structure of [(C2H5) 2NH2] 2 [Cd3Br8 (CdBr2)]· H2O: An augmented ribbon structure, Polyhedron 25(15) (2006) 2891-2896.

[21] L.-Y. Kong, X.-H. Lu, Y.-Q. Huang, H. Kawaguchi, Q. Chu, H.-F. Zhu, W.-Y. Sun, Unusual onedimensional branched-chain structures assembled by a novel imidazole-containing tripodal ligand with cadmium (II) salts and their fluorescent property, Journal of Solid State Chemistry 180(1) (2007) 331338.

[22] B. Gustafsson, M. Håkansson, S. Jagner, Copper (I)-mediated quaternisation of 1, 4-diazabicyclo [2.2. 2] octane (DABCO). Crystal structure of bis \{(1-chloromethyl-4-aza-1-azoniabicyclo [2.2. 2] octane)$\mu$-chloro-chlorocopper (I)\}, Inorganica chimica acta 358(4) (2005) 1309-1312.

[23] A. Kessentini, M. Belhouchet, J. Suñol, Y. Abid, T. Mhiri, Synthesis, crystal structure, vibrational spectra, optical properties and theoretical investigation of bis (2-aminobenzimidazolium)

tetraiodocadmate, Journal of Molecular Structure 1039 (2013) 207-213.

[24] M. Saber Lassoued, W. Ben Soltan, M.S. Abdelbaky, S. Ammar, A. Gadri, A. Ben Salah, S. GarcíaGranda, Structural, vibrational and optical properties of a new self-assembled organic-inorganic crystal (C4H7N2)[CdCl3 (H2O)], (2017).

[25] G. Breneman, R. Willett, Diethylenetriammonium tetrachloromanganate (II) chloride, Acta Crystallographica Section B: Structural Crystallography and Crystal Chemistry 37(6) (1981) 1292-1294.

[26] M.B. AlShammari, A. Kaiba, P. Guionneau, M.H. Geesi, T. Aljohani, Y. Riadi, Phase transitions, optical and electronic properties of the layered perovskite hybrid $[\mathrm{NH} 3(\mathrm{CH} 2) 2 \mathrm{COOH}] 2 \mathrm{CdCl} 4$ of $\mathrm{Y}$-aminobutyric acid (GABA), Chemical Physics Letters 702 (2018) 8-15.

[27] A. Altomare, M.C. Burla, M. Camalli, G.L. Cascarano, C. Giacovazzo, A. Guagliardi, A.G. Moliterni, G. Polidori, R. Spagna, SIR97: a new tool for crystal structure determination and refinement, Journal of Applied Crystallography 32(1) (1999) 115-119.

[28] S. GM, SHELX-97, release 97-2, University of Göttingen, Germany (1998).

[29] L.J. Farrugia, WinGX suite for small-molecule single-crystal crystallography, Journal of Applied Crystallography 32(4) (1999) 837-838.

[30] K. Brandenburg, DIAMOND 3.1 a., version 1.1 a, Crystal Impact GbR, Bonn, Germany 2005 (1997).

[31] C.F. Macrae, I.J. Bruno, J.A. Chisholm, P.R. Edgington, P. McCabe, E. Pidcock, L. Rodriguez-Monge, R. Taylor, J. Streek, P.A. Wood, Mercury CSD 2.0-new features for the visualization and investigation of crystal structures, Journal of Applied Crystallography 41(2) (2008) 466-470.

[32] I.D. Williams, Crystallography for chemists by Phillip E. Fanwick, Newcastle upon Tyne, Cambridge Scholars Publishing, (June 1, 2019), Language: English, 245 pp.,(Hardcover), ISBN-10: 1527531678, ISBN13: 978-1527531673, Product Dimensions: 5.9× 0.8× 8.2 inches, Taylor \& Francis, 2019. 
[33] F. Neve, O. Francescangeli, A. Crispini, Crystal architecture and mesophase structure of long-chain $\mathrm{N}$-alkylpyridinium tetrachlorometallates, Inorganica Chimica Acta 338 (2002) 51-58.

[34] P. Guionneau, Crystallography and spin-crossover. A view of breathing materials, Dalton Transactions 43(2) (2014) 382-393.

[35] K. Elmebrouki, S. Tamsamani, M. Khechoubi, Synthesis and characterization of new materials like perovskite [NH3-(CH2) n-NH3] ZnCl4 avec $n=8$ et 10, Journal of Asian Scientific Research 1(4) (2011) 216.

[36] I. Chaabane, F. Hlel, K. Guidara, Synthesis, Infra-red, Raman, NMR and structural characterization by X-ray Diffraction of [C $12 \mathrm{H} 17 \mathrm{~N} 2$ ] $2 \mathrm{CdCl} 4$ and [C $6 \mathrm{H} 10 \mathrm{~N}$ 2] $2 \mathrm{Cd} 3 \mathrm{Cl} 10$ compounds, PMC Physics B 1(1) (2008) 11.

[37] E. Smith, G. Dent, Modern Raman spectroscopy: a practical approach, John Wiley \& Sons2019. [38] L. McAfee, Infrared and Raman spectra of inorganic and coordination compounds. Part A: theory and applications in inorganic chemistry; Part B: application in coordination, organometallic, and bioinorganic chemistry, (Nakamoto, Kazuo), ACS Publications, 2000.

[39] R. Yadav, D. Swain, P.P. Kundu, H.S. Nair, C. Narayana, S. Elizabeth, Dielectric and Raman investigations of structural phase transitions in ( $\mathrm{C} 2 \mathrm{H} 5 \mathrm{NH}$ 3) $2 \mathrm{CdCl} 4$, Physical Chemistry Chemical Physics 17(18) (2015) 12207-12214.

[40] A. Kaiba, M.H. Geesi, P. Guionneau, T.A. Aljohani, L. Bih, H. Bih, S. Kassou, Synthesis, structural and Raman spectroscopic in organic- inorganic halide perovskites based on $\beta$-Alanine, Journal of Molecular Structure 1204 (2020) 127380.

[41] M. Hajji, A. Gharbi, T. Guerfel, Synthesis, crystal structure, vibrational spectra, optical properties and thermal analysis of a new chlorocadmate templated by 1-(2-ammoniumethyl) piperazinium, Journal of Inorganic and Organometallic Polymers and Materials 24(4) (2014) 766-775.

[42] W.E. Estes, D.B. Losee, W.E. Hatfield, The magnetic properties of several quasi two-dimensional Heisenberg layer compounds: A new class of ferromagnetic insulators involving halocuprates, The Journal of Chemical Physics 72(1) (1980) 630-638.

[43] M.A. Halcrow, Jahn-Teller distortions in transition metal compounds, and their importance in functional molecular and inorganic materials, Chemical Society Reviews 42(4) (2013) 1784-1795. [44] B. Sun, X.F. Liu, X.Y. Li, Y. Cao, Z. Yan, L. Fu, N. Tang, Q. Wang, X. Shao, D. Yang, Reversible Thermochromism and Strong Ferromagnetism in Two-Dimensional Hybrid Perovskites, Angewandte Chemie 132(1) (2020) 209-214.

[45] D. Nafday, D. Sen, N. Kaushal, A. Mukherjee, T. Saha-Dasgupta, 2D ferromagnetism in layered inorganic-organic hybrid perovskites, Physical Review Research 1(3) (2019) 032034.

[46] S.-H. Park, I.-H. Oh, S. Park, Y. Park, J.H. Kim, Y.-D. Huh, Canted antiferromagnetism and spin reorientation transition in layered inorganic-organic perovskite ( $6 \mathrm{H} 5 \mathrm{CH} 2 \mathrm{CH} 2 \mathrm{NH} 3) 2 \mathrm{MnCl} 4$, Dalton Transactions 41(4) (2012) 1237-1242. 